\title{
Analisis Implementasi Pendidikan Islam Wasathiyah dalam Mengembangkan Pemikiran Holistik Mahasiswa
}

\section{Analysis of Implementation of Wasathiyah Islamic Education in Developing of Students' Holistic Thinking}

\author{
U. Kusoy Anwarudin \\ Sekolah Tinggi Agama Islam (STAI) Syamsul 'Ulum Gunungpuyuh \\ Sukabumi, Jawa Barat \\ uk.anwarudin@gmail.com
}

\begin{abstract}
Abstrak
Tujuan penelitian ini adalah untuk memahami implementasi pendidikan Islam wasathiyah dalam mengembangkan pemikiran holistik mahasiswa Metode yang digunakan yaitu penelitian kualitatif. Penelitian dilaksanakan di STAI Syamsul Ulum Sukabumi selama dua bulan. Data diperoleh dari hasil indept interview dengan key informant ketua umum yayasan, para ketua bidang, para ketua jurusan, dosen dan mahasiswa. Kemudian data dianalisis dengan menggunakan langkah-langkah; data reduction, data display, dan conclution/ verification di dukung studi teoritis. Berdasarkan penelitian didapatkan hasil sebagai berikut: (1) Pengelolaan pendidikan Islam wasathiyah telah menjadi kebijakan yayasan dan efektif membangun pemikiran mahasiswa yang maderasi, menghargai pendapat orang lain, berkeadilan, toleran, rasional dan berakhlak mulia; (2) Strategi pendidikan dibagi dua yaitu internal dan eksternal kampus; (3) peran kiayi dan dosen belum optimal dalam pemanfaatan teknologi informasi sesuai kebutuhan; (4) untuk meningkatkan proses dan output pendidikan diperlukan peningkatan fasilitas, dan komitmen para kiayi dan dosen untuk meningkatkan kemampuhan pemanfaatan teknologi informasi sesuai dengan kebutuhan daya saing pendidikan dan tantangan era globalisasi saat ini.
\end{abstract}

Kata Kunci : Mahasiswa, Pendidikan Islam Wasathiyah \& Pemikiran Holistik

\section{Abstract}

The purpose of this study is to understand the implementation of Islamic education wasathiyah in developing students' holistic thinking The method used is qualitative research. The study was conducted at STAI Syamsul Ulum Sukabumi for two months. Data obtained from the results of In dept interview with key informant chairman of the foundation, heads of fields, the heads of departments, lecturers and students. Data were analyzed using the steps; data reduction, display data, and conclution / verification are supported by theoretical studies. Based on the research results can be concluded; (1) the management of Islamic education wasathiyah has become the foundation's policy and effectively build the thinking of students who maderasi, respect the opinions of others, fair, tolerant, rational and noble morals; (2) education 
strategy divided in two namely internal and external campus; (3) the role of kiayi and lecturers has not been optimal in the utilization of information technology as needed; (4) to improve educational processes and outputs required improvements in facilities, and the commitment of kiayi and lecturers to improve the effectiveness of the use of information technology in accordance with the educational competitiveness and challenges of the current era of globalization.

Keywords: Students, Wasathiyah Islamic Education \& Holistic Thought

\section{PENDAHULUAN}

Agama Islam merupakan agama yang sempurna, yang telah diimplementasikan secara utuh dan menyeluruh (kaffah) oleh Rasulullah SAW. Salah satu dari kesempurnaan ajaran Islam adalah mampu membentuk manusia yang berakhlak mulia (akhlakul karimah). Membangun akhlak mulia pada diri manusia dibutuhkan proses pembiasaan sejak dini dan melalui proses pendidikan secara bertahap dan berjenjang yang polanya bersumber dari al-Qur'an dan as-sunnah yang dilaksanakan secara dinamis dan komprehenship termasuk dalam menghadapi era globalisasi saat ini.

Dalam sejarah peradaban Islam selalu diwarnai perhelatan pengaruh antara teks dengan konteks. Sebagian kalangan berpendapat bahwa teks-teks keagamaan hendaknya diaplikasikan dengan konsisten sedemikian hingga kemurnian agama Islam dapat terjaga. Di sisi lain, banyak pula kalangan yang mencoba menggugat teks-teks keagamaan ini. Pihak yang terakhir ini menegaskan bahwa teks tidaklah lahir dari ruang yang kosong, ia muncul dari sebuah konteks sosial budaya maupun politik yang melengkapinya.

Dari dua kutub besar diatas, kita pun mengenal istilah naql dan aql, ahlu ar-ra'yi dan ahlu alhadits, juga pemikiran liberal dan pemikiran literal, yang masingmasing memiliki kesetiaan tersendiri terhadap teks maupun konteks. Meski masing-masing memiliki keunggulan yang harus diinsyafi adalah bahwa pemikiran yang terlalu tekstual maupun pemikiran yang sangat berlebihan dengan konteks memiliki titik lemah yang cukup rawan. Penerapan teks dengan apa adanya tanpa konteks dapat dikatakan merupakan pemerkosaan terhadap teks itu sendiri. 
Demikian pula, terlalu setia kepada konteks bisa terjadi adalah "akal-akalan", dimana teks diakali agar sesuai dengan nafsu seseorang atau kelompok. Dalam kondisi seperti ini, pola pemikiran dengan memediasi teks yang amat otoritatif dengan konteks yang terus bergerak dinamis perlu terus ditumbuh kembangkan sepanjang sejarah keagamaan. Dengan demikian, diharapkan akan muncul para pemikir dan ahli-ahli yang moderat, yang tidak terlalu "saklek", namun tidak terlalu "Liar" (Yasid, 2010)

Islam wasathiyah sebagai tema Musyawarah Nasional ke-9 Majelis Ulama Indonesia (MUI) adalah upaya menunjukan wajah Islam Indonesia yang layak menjadi contoh bagi dunia. Majelis Ulama Indonesia (MUI) telah menggelar Musyawarah Nasional (Munas) ke-9 pada tanggal 24 hingga 27 Agustus di Surabaya Jawa Timur dengan mengusung tema "Islam wasathiyah untuk Indonesia dan Dunia yang Berkeadilan dan Berkemajuan". KH Ma'ruf Amin, Ketua Umum MUI menjelaskan Islam wasathiyah adalah Islam moderat, yang toleran, damai, dan santun. Ia mengatakan, Islam wasathiyah tidak menghendaki terjadinya konflik. Selain itu, model tersebut juga tidak memaksakan diri dan menghargai perbedaan.

Tiga Ormas Islam terbesar di Indonesia, yakni Nahdlatul Ulama, Muhammadiyah, dan Majelis Ulama Indonesia (MUI) pada Musyawarah Nasional (Munas), tidak hanya menyusun kepengurusan baru, namun merumuskan konsep Islam yang dinilai mampu menjawab problematika di Indonesia. Konsep tersebut, yakni Islam berkemajuan (Muhammadiyah), Islam nusantara (Nahdlatul Ulama), dan Islam wasathiyah (Majelis Ulama Indonesia).

Dalam pandangan MUI, Islam wasathiyah melihat ajaran Islam sebagai rahmatan lil alamin, rahmat bagi segenap alam semesta. Islam wasathiyah adalah "Islam Tengah" untuk terwujudnya umat terbaik (khairu ummah). Allah SWT menjadikan umat Islam pertengahan (wasath) dalam segala urusan agama, seperti hal kenabian, syari'at dan lainnya.

Munas ke-9 MUI meyakini bahwa Islam wasathiyah wajib diamalkan secara istiqomah oleh seluruh umat Islam Indonesia dan dunia sehingga menjadi Syuhada' 
ala al-nas (saksi kebenaran Islam) untuk mewujudkan kehidupan keagamaan yang berkemajuan dan toleran, membentuk kehidupan kemasyarakatan yang damai dan saling menghargai, merealisasikan kehidupan kebangsaan yang inklusif, bersatu dan berkeadaban dan menciptakan kehidupan kenegaraan yang berkeadilan dan demokratis.

Secara historis Islam wasathiyah telah menjadi rujukan ulama-ulama Indonesia sejak dahulu, baik dalam pendidikan, maupun dalam pembinaan umat, hanya konteks sosial-politik yang berbeda yakni berupaya memperjuangkan keadilan melalui kemerdekaan dari cengkraman kolonialisme, sehingga para ulama dalam pendidikan dan pembinaannya lebih berkonsentrasi pada pendekatan menumbuhkan penguatan aqidah, ibadah, persatuan, patriotisme dan nasionalisme.

Mengingat begitu esensialnya isu tersebut, maka dalam kajian ini peneliti menganggkat topik tentang "Analisis Implementasi Pendidikan Islam wasathiyah dalam Mengembangkan Pemikiran Holistik Mahasiswa".

\section{METODE PENELITIAN}

Metode yang digunakan yaitu penelitian kualitatif. Penelitian dilaksanakan di STAI Syamsul Ulum Sukabumi selama dua bulan. Data yang diperoleh dari hasil wawancara mendalam (indept interview) dengan key informant ketua umum yayasan, para ketua bidang, para ketua jurusan, dosen dan mahasiswa.

Data yang sudah terkumpul diolah dan dianalisis dengan langkah-langkah: Reduksi data (data reduction), penyajian data (data display) dan penarikan kesimpulan (conclution/ verification) di dukung studi teoritis.

\section{HASIL DAN PEMBAHASAN}

\section{A. Pengertian Pendidikan Islam Wasathiyah}

Ibunu Faris menjelaskan dalam kitab "Maqayisul-Lughoh" bahwa rangkaian huruf (و س b) menunjukan makna adil dan pertengahan. "عدل الثيئ perkara yang paling adil) adalah "اوسطة" (yang paling tengah. Allah Swt. Berfirman "....sebagai umat yang pertengahan" (Al-Baqarah [2]: 143). "وسط القوم" adalah kaum yang paling mulia dan paling bermartabat (Al-Hasyr [59]: 06). 
Sebelum memahami makna pendidikan Islam wasathiyah, terlebih dahulu kita mengetahui makna parsial dari pendidikan Islam dan wasathiyah itu sendiri. Ahmad Tafsir (1991) menyatakan bahwa pendidikan Islam adalah bimbingan terhadap seseorang agar berkembang secara maksimal sesuai dengan ajaran Islam. Sedangkan pendidikan Islam menurut Muhyidin \& Sutrisno (2012) yaitu proses penyiapan generasi muda untuk mengisi peranan memindahkan pengetahuan dan nilai-nilai Islam yang diselaraskan dengan fungsi manusia untuk beramal di dunia dan memetik hasilnya di akhirat.

Sanusi (2017) menyatakan terdapat seperangkat nilai-nilai yang harus terwujud dalam kehidupan manusia yang harus ditanamkan dalam proses pendidikan sehingga manusia dalam hidupnya bernilai. Nilainilai tersebut dirumuskan dalam enam kategori "sistem nilai", yaitu ; (1) Nilai Teologis; yang tercermin antara lain dalam rukun iman, rukun islam, tauhid, ibadah, ikhsan, istigfar, ikhlas, tobat, ijtihad, khusu dan istiqomah; (2) Nilai EtisHukum; yang tercermin antara lain dalam hormat, baik, rendah hati, setia, dapat dipercaya, jujur, bertanggungjawab, i'tikad baik, setia, adil, damai, sabar, memaafkan, menolong, toleransi dan harmonis; (3) Nilai Estetik; terwujud antara lain, dalam bagus, bersih, indah, cantik, manis, menarik, serasi, romantik, dan cinta kasih; (4) Nilai Logis-rasional; yang terwujud antara lain, dalam logika/ cocok antara fakta \& kesimpulan, tepat, sesuai, jelas, nyata, identik/ ciri, proses, keadaan/ kesimpulan cocok; (5) Nilai fisik-fisiologis; yang terwujud jelas unsur-unsurnya, fungsinya, ukuran-ukurannya, kekuatannya, perubahannya, lokasinya, asal usulnya, sebab akibatnya; (6) Nilai teleologik; yang terwujud dalam berguna, bermanfaat, sesuai fungsinya, berkembang/ maju, teratur/ disiplin, inegratif, produktif, efektif, efisien, akuntabel, inovatif. Dari uraian tersebut, artinya bahwa pendidikan Islam tidak bisa dimaknai sebatas tranfer of knowledge saja, akan tetapi juga transfer of value serta berorientasi dunia akhirat.

Selain itu menurut Arifin (2003) pendidikan Islam adalah suatu sistem kependidikan yang mencakup seluruh aspek kehidupan yang dibutuhkan oleh hamba Allah, 
sebagaimana Islam telah menjadi pedoman bagi seluruh aspek kehidupan manusia, baik duniawi maupun ukhrowi. Dan menurut Daradjat (2005) secara umum dapat dikatakan bahwa pendidikan Islam itu adalah "pembentukan kepribadian muslim".

Berdasarkan berbagai pengertian diatas, dapat disimpulkan bahwa pendidikan agama Islam adalah pendidikan yang dilaksanakan berdasarkan ajaran Islam sebagai pandangan hidupnya untuk kebahagiaan di kehidupan ini dan kehidupan mendatang.

\section{Adapun makna al-} wasathiyah secara istilah, adalah sebuah kondisi terpuji yang menjaga seseorang dari kecendrungan menuju dua sisi /sikap yang ekstrim, sikap berlebihlebihan dan melalaikan. alwasathiyah juga bisa diartikan dengan kondisi seimbang dan setara antara dua sisi; dimana satu sisi/ aspek tidak melampaui aspek yang lain, sehingga tidak ada yang berlebihan dan tidak pula melalaikan, tidak melampaui batas dan mengurangi. Artinya makna alwasathiyah adalah sikap mengikuti yang lebih utama, lebih pertengahan, lebih baik dan lebih sempurna.

Makna dari wasathiyah itu sendiri adalah secara bahasa berasal dari kata wasath yang berarti sesuatu yang ada di tengah. Dalam mufrodat Alfazh al-Qu'an disebutkan secara bahasa bahwa kata wasath ini berarti, " Sesuatu yang memiliki dua belah ujung yang ukurannya sebanding". Istilah wasathiyah ini bersumber dari dalil berikut:

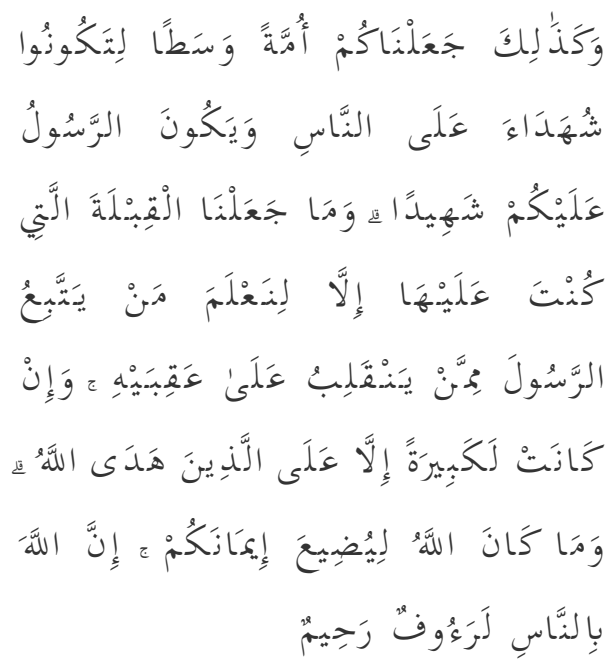

"Dan demikian (pula) kami telah menjadikan kamu (Umat Islam), umat yang adil dan pilihan agar kamu menjadi saksi atas (perbuatan) kamu dan kami tidak menetapkan kiblat yang menjadi kiblatmu (sekarang) melainkan agar kami mengetahui (supaya nyata) siapa yang mengikuti Rosul dan siapa yang membelot, dan 
sungguh (pemindahan kiblat) itu terasa amat berat, kecuali bagi orang-orang yang telah diberi petunjuk oleh Allah, dan Allah tidak akan menyia-nyiakan imanmu. Sesungguhnya Allah Maha Pengasih lagi Maha Penyayang kepada manusia". (Q.S al-Baqarah [2]:143)

Wasath dalam agama adalah berpegang teguh dengan sirah Nabi. Ghuluw dalam agama adalah kelewat batas (berlebihan) dan taqshir (kurang) adalah tidak sampai kepadanya. Contohnya seseorang berkata "saya bangun sepanjang malam (beribadah) dan tidak tidur sepanjang tahun, karena sholat adalah ibadah yang paling utama, maka saya ingin menghidupkan semuanya dengan shalat". Kami katakan ini ghuluw dalam agama Allah SWT dan tidak berada di atas kebenaran. Kasus seperti ini pernah terjadi di zaman Rasulullah SAW, berkumpul beberapa orang, salah seorang dari mereka berkata "saya selalu bangun dan tidak tidur", yang lain berkata "saya selalu puasa dan tidak berbuka disiang hari”, yang ketiga berkata "saya tidak menikahi wanita". Maka hal itu sampai kepada Nabi SAW, Lalu beliau bersabda :

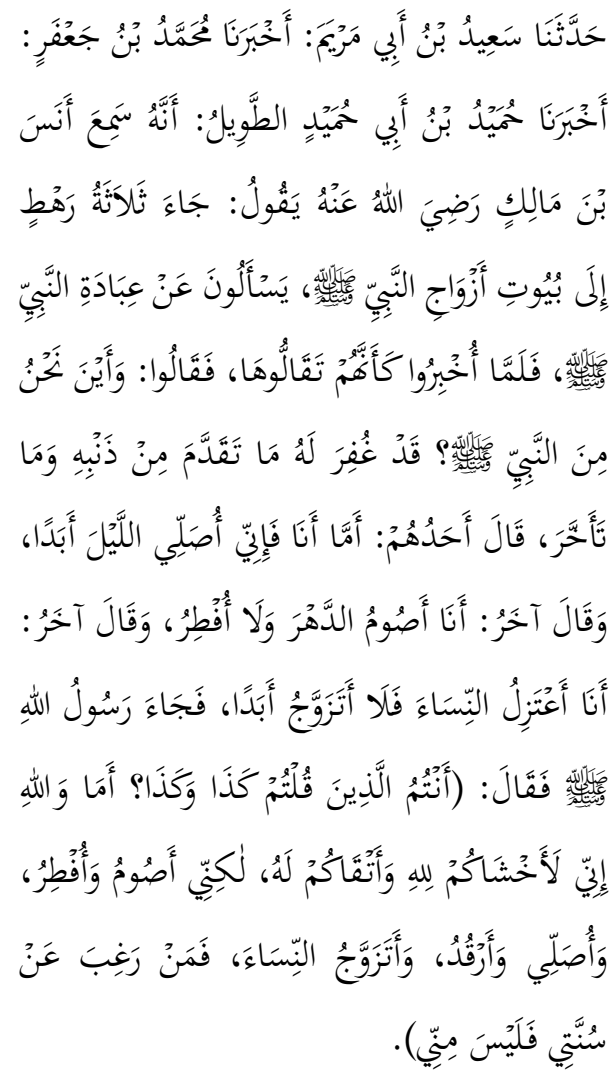

"Ada tiga orang mendatangi rumah istri-istri Nabi SAW dan bertanya tentang ibadah Nabi SAW dan setelah diberitakan kepada mereka, sepertinya mereka merasa hal itu masih sedikit bagi mereka. Mereka berkata,"Ibadah kita tak ada apa-apanya di banding Rasulullah SAW, bukankah beliau sudah diampuni dosa-dosanya yang telah dan juga yang akan datang?, Salah seorang dari mereka berkata, "Sungguh, aku akan shalat malam selamalamanya. Kemudian yang lain 
berkata, "Kalau aku, maka sungguh, aku akan berpuasa Dahr (setahun penuh) dan aku tidak akan berbuka. Dan yang lain lagi berkata, "Aku akan menjauhi wanita dan tidak akan menikah selama-lamanya. "Kemudian datanglah Rasulullah SAW kepada mereka seraya bertanya; "kalian berkata begini dan begitu. Ada pun aku, demi Allah, adalah orang yang paling takut kepada Allah di antara kalian, dan juga paling bertaqwa. Aku berpuasa dan juga berbuka, aku shalat dan juga tidur serta menikahi wanita. Barang siapa yang benci sunnahku, maka bukanlah dari golonganku (AlBukhori 5063 dan Muslim 1401)

Mereka telah bertindak ghuluw dalam agama dan Rasulullah SAW berlepas diri dari mereka, karena mereka membenci sunnahnya, yaitu puasa dan berbuka, bangun dan tidur, serta menikahi wanita, dan ibadah seperti itu bertentangan dengan Islam wasathiyah.

Yusuf al-Qaradawi mengatakan bahwa kata wasathiyah juga diungkapkan dengan istilah tawazun (seimbang) maksudnya adalah bersikap tengahtengah dan seimbang antara dua aspek yang saling bersebrangan, dimana salah satu aspek tidak mendominasi seluruh pengaruh dan menghilangkan pengaruh aspek yang lain atau dimana salah satu aspek tidak mengambil hak yang berlebihan sehingga mempersempit hak aspek yang lain.

Contoh aspek-aspek yang saling bersebrangan adalah aspek ruhiyah (spiritual) dan madiyah (material); aspek individual dan aspek kepentingan kolektif; aspek realitas dan idealitas; aspek yang sikap konstan (dogmatik) dan aspek yang mungkin berubahrubah. Adapun makna seimbang diantara kedua aspek yang berlawanan, adalah membuka ruang masing-masing aspek secara luas; memberikan hak masingmasing secara adil dan seimbang, tanpa penyimpangan, berlebihlebihan, pengurangan, tindakan melampaui batas atau merugikan (Al-Qordowi;17).

Kata al-wasathiyah tidak familier dalam kitab-kitab fiqih dan buku sastra lama; namun, maknanya terdapat didalamnya, digantikan dengan istilah al-adlu (sikap adil), al-I'tidal (seimbang), al-qoshdu (Efisien dan tepat sasaran) dan lain sebagainya.

Ar-Razi (1993) menyebutkan ada beberapa makna yang satu 
sama lain saling berdekatan dan saling melengkapi.

Pertama; wasath berarti adil, makna ini didasarkan pada ayatayat yang semakna, hadits nabi, dan beberapa penjelasan dari sya'ir Arab mengenai makna ini. Berdasarkan riwayat al-Qaffal dari al-Tsauri dari Abu Sa'id al-Khudry dari Nabi SAW, bahwa ummatan wasathan adalah umat yang adil.

Kedua; wasath berarti pilihan, al-Razi memilih makna ini dibandingkan dengan maknamakna lainnya, karena beberapa alasan, antara lain; kata ini secara bahasa paling dekat dengan makna wasath dan paling sesuai dengan ayat yang semakna dengannya yaitu:

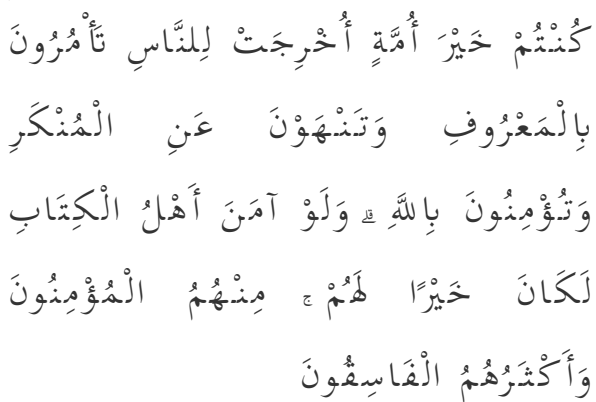

"Kaтu adalah umat yang terbaik yang dilahirkan untuk manusia, menyuruh kepada yang ma'ruf, dan mencegah dari yang munkar, dan beriman kepada Allah. Sekiranya ahli Kitab beriman, tentulah itu lebih baik bagi mereka, diantara mereka ada yang beriman, dan kenyakan mereka adalah orangorang yang fasik”. (QS.Ali Imran [3]: 110)

Ketiga; wasath berarti yang paling baik.

Keempat; wasath berarti orang-orang yang dalam beragama berada di tengah-tengah antara ifrath (berlebih-lebihan hingga mengada-adakan yang baru dalam agama) dan tafrith (mengurangngurangi ajaran agama) (Tafsir AlRazi, Jilid II, hal 389-390).

Setelah memperhatikan makna "ummah al-wasath" yang berarti umat yang secara konsisten berpegang pada petunjuk Allah SWT, dapat kita fahami bahwa makna dari wasath ini sifatnya sesuatu yang sudah dipatenkan dalam al-Qur'an sendiri, buka makna yang diberi sifat baru.

Dalam hal ini, al-Qur'an telah menetapkan bahwa ajaran Islam yang bersumber dari alQur'an dan al-Sunnah adalah ajaran yang adil, terbaik, terpilih, dan moderat sehingga umat yang secara konsisten melaksanakannya, maka secara otomatis dia akan menjadi umat yang sifatnya sama dengan ajaran yang dilaksanakannya. 
(U. Kusoy Anwarudin)

Jadi, "Pendidikan Islam Wasathiyah" dapat diartikan sebagai pendidikan yang memadukan antara teks al-Qur'an dan konteks atau realita yang ada seiring dengan perkembangan zaman.

\section{B. Pendidikan Islam Wasathiyah STAI-STISIP Syamsul 'Ulum Sukabumi}

\section{Latar Belakang}

Gagasan pendidikan Islam wasathiyah merupakan konsep (Alm) KH Ahmad Sanusi. Dalam konteks yang berbeda beliau merupakan pendiri Pondok Pesantren Syamsul Ulum Gunungpuyuh Sukabumi, beliau salah seorang ulama besar dan produktif di Jawa Barat, dan termasuk anggota BPUPKI. Sebagai ulama produktif disamping beliau merupakan pendidik dan pembimbing para santri dan masyarakat, semasa hidupnya beliau telah banyak menulis berbagai kitab yang bermanfaat digunakan oleh para kiayi, santri dan kelompok akademisi saat ini. Diantara karyanya yang monumental adalah Tafsir Raudhotul Irfan, Tamsiatul Muslimin, Lu'luun-Nadid dsb. Sebagai pejuang beliau merupakan pemimpin gerakan lasykar
Sabilillah dan Hisbullah melawan tentara Belanda, termasuk memimpin pertempuran melawan tentara NICA yang terkenal dengan monumen Bojong KokosanSukabumi. Pada tahun 1918 beliau mendirikan

Organisasi kemasyarakatan bernama $\mathrm{Al}$ Ittihadiyatul Islamiyah (AII), organisasi ini kemudian dibubarkan oleh Jepang kemudian berganti nama menjadi Persatuan Umat Islam Indonesia (PUII), dan untuk melebarkan sayap persatuan umat, maka organisasi ini di adakan Fusi (dilebur dan disatukan) dengan organisasi POI yang didirikan oleh KH.Abdul Halim (Majalengka), dan berubah bernama Persatuan Umat Islam (PUI) yang eksis hingga saat ini.

\section{Pedoman Pendidikan Islam Wasathiyah}

Salah satu khazanah keilmuan yang merupakan konsep dasar karya KH.Ahmad Sanusi adalah: (1) INTISAB merupakan konsep landasan perpikir dan berprilaku bagi setiap muslim kahususnya pada jamaah PUI; (2) Itslahus-Samaniyah, merupakan konsep delapan arah perbaikan dalam kehidupan muslim agar tetap lurus dan konsisten dalam ajaran Islam faham akhlusunnah Wal- 
Jamaah kahususnya untuk jamaah PUI, konsep tersebut menjadi pedoman yang semuanya bersumber dari Al-Qur'an, AsSunnah,yang dipandu oleh Ijma ulama serta kontekstual (Lubis, 2007)

Kedua konsep dasar tersebut bertujuan untuk membimbing umat agar memiliki pribadi dan keluarga; Beriman dan bertaqwa, toleran, santun, adil, seimbang, menghargai pendapat orang lain, tidak ekstrim, kekeluargaan, menjaga persatuan, manjaga syi'ar Islam, uraian tersebut sejalan dengan konsep pendidikan Islam wasathiyah

\section{Tujuan Pendidikan Islam Wasathiyah}

Tujuan utama pembinaan ini sebagai berikut: Membentuk karakter yang berkualitas iman dan taqwa (spiritual,) intelektual, emosional dan sosial serta berjiwa nasionalis.

Outcome dari pembinaan ini menjadikan alumni yang tangguh/ stabil, berperilaku jujur (amanah), moderat, bersikap adil, santun (etis), toleran, tidak ekstrim, dan mampu menjaga \& memperkuat persatuan, serta bangga sebagai bangsa Indonesia.

Polarisasi pendidikan Islam wasathiyah prinsipnya dibangun melalui lima pilar strategi pembinaan : (1) Pilar kajian kitabkitab kuning; (2) Pilar Kepemimpinan; (3) Pilar IPTEK; (4) Pilar kebangsaan dan Sosial Budaya, dan (5) Pilar Hukum ketata Negaraan.

Arah pembinaan masingmasing pilar telah dirumuskan dalam buku panduan masingmasing serta ditunjuk dua-tiga orang pembimbing (kiayi, dosen) yang memiliki kemampuhan sesuai dengan lima pilar tersebut.

Pendidikan dan pembinaan tersebut dilakukan dua kali dalam seminggu, masing-masing tiga jam (180 menit) yang dilaksanakan setelah selesai shalat Isya bertempat di ruang kelas, pada setiap bulan dilakukan evaluasi terhadap materi yang telah disampaikan.

\section{Strategi Pendidikan Islam Wasathiyah Mahasiswa. \\ STAI-STISIP Syamsul Ulum} Sukabumi berada dalam kompleks Pesantren Syamsul Ulum Gunungpuyuh Sukabumi, sebagian besar mahasiswa merupakan santri yang bermukim di pesantren yang berasal dari berbagai daerah dan latar belakang yang bervariasi berjumlah 1246 orang mahasiswa yang terdiri dari lima program 
studi, yakni; Pendidikan Agama Islam (Tarbiyah), Hukum Islam (Syariah), Manajemen Pendidikan Islam (MPI), Ilmu Administrasi Negara (IAN), dan Ilmu Pemerintahan (IP).

Seluruh mahasiswa diwajibkan mengikuti dan terintegrasi dengan sistem pesantren agar mahasiswa memiliki tambahasan ilmu pengetahuan dan wawasan agama secara mendalam dan komprehenship meskipun pola dan sistem pembinaannya berbeda dengan pola kajian, dialogis, dinamis, kontekstual, dan varian.

Hasil analisa menunjukan, bahwa Pendidikan Islam wasathiyah yang diadopsi dari konsep dan gagasan KH.Amhad Sanusi telah bergulir selama ini yang secara teknis telah dilakukan penyesuaian dengan tantangan zaman, khususnya dilengkapi dengan pemanfaatan teknologi infomasi menjadi sangat efektif yang secara umum berhasil dengan baik semua kegiatan pendidikan Islam wasathiyah bertanggungjawab kepada ketua III bidang Kemahasiswaan masingmasing, secara teknis dikoordinasikan oleh pengurus BEM masing masing prodi, kemudian dibentuk menjadi beberapa kelompok studi.

\section{Metode Pendidikan Islam Wasathiyah}

Metode yang digunakan dalam pembinaan tersebut, secara umum; Metode ceramah, tanya jawab, diskusi kelompok, problem solving, khalaqoh, penugasan, eksplorasi, dan praktek kepemimpinan praktis. Program pembinaan ini dilakukan sejak mahasiswa berada pada semester empat hingga semester delapan (4 semester/2 tahun).

\section{Menanamkan \\ Materi \\ Pendidikan Islam Wasathiyah}

Terdapat beberapa prinsip mendasar materi-materi yang ditanamkan kepada mahasiswa pada pendidikan Islam wasathiyah yaitu sebagai berikut :

- $\quad$ Sebagai mahasiswa muslim yang baik keyakinan akan keselamatan dan kebahagiaan yang hakiki baik di dunia dan akhirat hanya akan deperoleh oleh konsistensi Iman dan Taqwa. Dan dipastikan akan senantiasa berhadapan dengan tantangan baik bersifat internal maupun eksternal. Kekuatan Iman dan taqwa dalam segala aspek kehidupan akan mencerminkan kejujuran, keadilan 
dan amanah dan kondisi yang stabil.

- Sebagai generasi muda yang beriman wajib meyakin bahwa setiap manusia dari sudut pandang penciptaannya (ontologis) memiliki kemuliaan, apapun ras, warna, kulit, suku bangsa bahkan termasuk agamanya. Maka hak kemuliaan sebagai manusia siptaan Allah wajb untuk dihormati dan dilindungi dan dipelihara. Kecuali dengan pelanggaran yang telah ditentukan dalam syariat Islam dan perundang-undangan yang berlaku.

- $\quad$ Sebagai seorang generasi muda muslim yang ditakdirkan Allah menjadi warga negara Indonessia perlu disyukuri, karera telah dianugrahi wilayah yang luas, subur, dan mayoritas muslim, sebagai generasi muda harus memiliki kesiapan, kemampuhan (skill) untuk senantiasa memberikan yang terbaik dan bermanfaat, menjaga keanekaragaman, bersaing dan bersanding secara sehat dan demokratis, bekerja dengan penuh rasa tanggungjawab untuk menjagi bangsa yang maju dan bermartabat.

- $\quad$ Bersikap apresiatif terhadap fakta keragaman dan berlapang dada terutama kelak menjadi pemimpin dalam level apapun, karena perbedaan keyakinan dan agama merupakan sesuatu yang qodrati dari Allah SWT. Karenanya, tidaklah mungkin bagi seorang muslim memaksanak atau intimidasi, apalagi bersifat radikal dan teror terhadap orang lain untuk masuk ke dalam Islam. Jiwa pemimpin harus akomodatif dan proporsional serta teguh memegang prinsip. Jiwa persatuan dan nasionalisme harus mampu jadi perekat dalam kepemimpinan (pemerintahan, pendidikan, pengadilan, atau kepemimpinan sosial lainnya), sebab hanya oleh generasi muslim yang mayoritas ini nasib negara-bangsa Indonesia akan memperoleh kemajuan dan kejayaan.

- Memahami bahwa perintah dakwah dalam Islam bertujuan terwujudnya transformasi dan perubahan kepada kebaikan dan kebenaran, baik pada level pribadi, keluarga maupun masyarakat, dilakukan dengan cara persuasif dan educatif serta komunikatif dan elegan, bukan indoktrinasi, ektrim dan memfitnah. Disertai sebuah pemahaman bahwa, Allah tidak membebani kita untuk bertanggungjawab atas kekufuran orang-orang kafir. Jadilah sosok mubaligh yang disegani oleh semua 
kalangan dengan sumber yang tekstual dan kontekstual secara dinamis.

- Allah SWT telah mewajibkan kita untuk menuntut Ilmu, Sebagai generasi muda muslim hendaknya tidak merasa puas dengan ilmu yang telah diperoleh, kembangkan, dan manfaatkan serta terus lakukan pendalaman dan kajian terhadap berbagai referensi yang pasti akan bermanfaat.

\section{KESIMPULAN}

Gagasan dan proses pendidikan dan pembinaan Islam wasathiyah STAI-STISP Syamsul Ulum yang dikemas dengan misi dan program pesantren Syamsul Ulum PUI yang intinya diadopsi dari substansi Intisab dan ItslahutsSanamiyah yang merupakan karya KH Ahmad Sanusi telah efektif dan mencapai output yang diharapkan, meskipun masih perlu ada peningkatan dan perbaikan. Hal ini terbukti pada sebagian besar telah berhasil menunjukan alumi yang berfungsi dan memiliki peran aktif, religius daan memiliki keunggulan dan kapasitas tersendiri dalam melaksanakan tugas dan kewajibannya yang bekerja dibergai institusi pendidikan, pemerintah, pengadilan agama, legislatif terutama yang menjadi kiayi, Mubaligh, dan aktifitas sosial lainnya patut menjadi kebangaan bersama. (Hasil wawancara dengan para kepala dinas, OPD dan kementrian Agama kota dan kabupaten Sukabumi (Maret 2018) Pendidikan Islam wasathiyah adalah pendidikan Islam yang bersifat moderat, dalam hal ini merefleksi pendidikan di STAISTISIP Syamsul Ulum Sukabumi yang terpadu dengan mengkombinasikan kurikulum pesantrenya yang menerapkan pendidikan Islam moderat yang disesuaikan dengan kebutuhan dan tantangan masyarakat pada saat ini. Sebagaimana diketahui bahwa seluruh permasalahanpermasalahan yang muncul saat ini tidak bisa serta merta dikembalikan pada teks namun perlu dikaji secara kontekstual. Pendidikan Islam Wasatiyah ini muncul diharapkan dapat mengembalikan kewibawaan Islam di mata dunia. Islam merupakan agama yang rahmatan lil-'alamin, yang berarti membawa rahmat bagi seluruh alam. Pendidikan Islam perlu adanya penyesuaian dengan lajunya zaman yang semakin kompleks dan modern. 
Islam sebagai agama berferan sebagai pandangan hidup, Ia mempengaruhi pikiran, perasaan, sikap dan perilaku seseorang, keluarga dan masyarakat serta lingkungannnya. Oleh sebab itu setiap peran mubalig (da'i) yang santun, toleran dan arif dalam setiap melakukan transformasi ajaran Islam, dituntut bukan hanya mentrasformasi ilmu semata, namun dibutuhkan transformasi nilai (sistem nilai) secara utuh dan mendalam melalui kajian dibarengi dengan metode yang tepat sasaran, serta tetap bersumber secara tekstual (al-Qur'an dan as-Sunnah), serta dikombinasikan dengan nilainilai dan perkembangan secara kontekstual, sehingga pesan-pesan materi ajaran Islam dapat diterima secara sejuk oleh segala lapisan masyarakat.

Pendidikan Islam, khususnya di Indonesia sudah seharusnya mengacu pada konsep wasathiyah (moderat). Hal ini untuk mengantisipasi adanya kekacauan dan radikalisme yang semakin mengwatirkan. Artinya perlu adanya perubahan dalam kurikulum pendidikan, yaitu dengan mengkombinasikan kurikulum pesantren dan kurikulum pendidikan yang sesuai dengan kebutuhan dan tantangan zaman.

\section{DAFTAR PUSTAKA}

Ar-Razi, A. A. M. F. (1993). Tafsir Fakhrurrazi al-Musytahar bi at-Tafsir alKabir wa Mafatih al-Ghaib. Vol 1: Beirut: Dar al-Fikr.

Arifin, H.M. (2003). Ilmu Pendidikan Islam, Tinjauan Teoritis dan Praktis Berdasarkan Pendekatan Interdisipliner, Jakarta: Bumi Aksara.

Daradjat, Z. (2005). Pendidikan Islam Dalam Keluarga Dan Sekolah. Jakarta: Ruhama.

Maunah, B. (2009). Landasan Pendidikan, Yogyakarta: Teras.

Muhyidin, \& Sutrisno. (2012). Pendidikan Islam Berbasis Problem Sosial, Yogyakarta: Ar-Ruzz Media. 
Lubis, N. H. (2011). Sejarah Perkembangan Islam di Jawa Barat, Yayasan Masyarakat Sejarawan Indonesia Cabang Jawa Barat dan Pemerintah Provinsi Jawa Barat.

Ramayulis. (2012). Sejarah Pendidikan Islam, Napak Tilas Perubahan Konsep, Filsafat dan Metodologi Pendidikan Islam dari Era Nabi SAW sampai Ulama Nusantara, Jakarta: Kalam Mulia

Sanusi, A. (2017). Sistem Nilai, Alternatif Wajah-Wajah Pendidikan, Bandung; Nuansa.

Tafsir, (A). (1991). Ilmu Pendidikan dalam Perspektif Islam, Bandung: Remaja Rosdakarya.

Yasid, A. (2010). Membangun Islam Tengah, Refleksi Dua Dekade Ma'had Aly Situbondo, Yogyakarta. 